\title{
Hrvatsko selo na početku 21. stoljeća - studija slučaja općina Gornja Rijeka
}

\section{Sanja Klempić Bogadi}

Institut za migracije i narodnosti, Zagreb, Hrvatska

e-mail:sanja.klempic@imin.hr

\section{Sonja Podgorelec}

Institut za migracije i narodnosti, Zagreb, Hrvatska e-mail: sonja.podgorelec@imin.hr

\author{
Monika ̌́abijan \\ Dropkovec, Hrvatska \\ e-mail: monika.sabijan@gmail.com
}

SAŽETAK U radu se iznosi dio rezultata provedenog empirijskog istraživanja koje je imalo za cilj produbiti znanstvene spoznaje o kvaliteti života u ruralnim područjima Hrvatske na primjeru općine Gornja Rijeka. Analiziraju se potencijalna migracija stanovništva, procjena ekoloških prednosti i nedostataka života u promatranim ruralnim zajednicama, infrastrukturna opremljenost naselja, subjektivna procjena doživljaja pripadanja ruralnoj zajednici te prijedlozi mjera za poboljšanje kvalitete života. Istraživanje je provedeno metodom ankete tijekom studenog i prosinca 2012. godine na uzorku od 170 ispitanika starih od 18 do 60 godina, što čini otprilike 10\% ukupnog broja stanovnika općine.

Općina Gornja Rijeka dijeli sličnosti s većinom ruralnih područja u Hrvatskoj, koje karakterizira ekonomska nerazvijenost i demografska regresija. Depopulacija i starenje kao dominantni demografski procesi oblikuju malu zajednicu koju obilježava slabija obrazovna struktura stanovnika, što uz gotovo nepostojeću lokalnu inicijativu čini ograničavajuće čimbenike za pokretanje gospodarskih aktivnosti.

Usprkos brojnim ograničavajućim čimbenicima života u ovom području, ispitanici pokazuju visok stupanj zadovoljstva životom u ruralnoj sredini, ali napominju da je pojedine sadržaje društvene i komunalne infrastrukture potrebno značajno unaprijediti. Iako su svjesni brojnih prednosti života u ruralnim sredinama kao što su očuvana priroda, čist zrak, smirenosti i jednostavnost života, manji troškovi života, ekonomskih ih razlozi tjeraju na razmišljanje o migraciji.

Ključne riječi: selo, općina Gornja Rijeka, ruralnost, migracija, infrastruktura, kvaliteta života. 


\section{Uvod}

Promjene u načinu života i prirodi društvenih odnosa u ruralnim područjima Hrvatske posljednjih pedesetak godina odvijale su se u skladu s dinamikom pojedine društvene sredine, pod utjecajem većih i gušće naseljenih urbanih prostora te prije svega u raznim razdobljima određene gospodarske politike spram sela, regija, ali i razvoja zemlje u cjelini. Tako krajem 1950-ih godina, s dominantnom orijentacijom na industriju u gospodarskom razvoju tada socijalističke Hrvatske, selo i seoski način života doživljavaju društvenu i gospodarsku krizu, koja se uz razne uspone i padove nastavlja tijekom cijelog promatranog razdoblja, dakle i s promjenom društveno-političkog sustava 1990. godine, odnosno promjenom planske u tržišnu ekonomiju, te se produbljuje neravnomjernim ekonomskim razvojem zemlje i na svojevrstan način kulminira $s$ aktualnom gospodarskom krizom posljednjih šest godina. Ruralna ekonomija pretežno je ovisna o primarnoj djelatnosti: poljoprivredi, stočarstvu i šumarstvu. U navedenom razdoblju selo i dominantne grane proizvodnje doživjele su razne više-manje neuspješne (pokušaje) reforme, ali i prepuštanje stihiji: agrarne reforme, kolektivizaciju (komasaciju), nacionalizaciju i naposljetku od 1990-ih ponovnu privatizaciju zemljišta, stvaranje porodičnih zadruga i kombinata pa potom njihov raspad, neplanska financijska ulaganja u određene poljoprivredne kulture i vrste stočarstva, neracionalno i nekontrolirano dijeljenje poljoprivrednih poticaja i sl. (Puljiz, 1970.; Štambuk, 2002.). Iako je ruralni prostor pretežno prostor poljoprivrede, znatnoj većini seoskog stanovništva poljoprivreda više nije osnovna djelatnost, te dohodak ostvaruju radom u drugim djelatnostima (Štambuk, 1990.; Hodžić, 2000.).

Ulazak u Europsku uniju hrvatski ruris dočekao je s velikim brojem sitnih ${ }^{1}$ posjeda neprimjerenih za ozbiljniju tržišnu proizvodnju, nedostatnim ulaganjima, s jedne strane zaostalom, a s druge pak preskupom i neadekvatnom mehanizacijom, opterećenošću seoskog domaćinstva skupim kreditima, (ne)organiziranim otkupima proizvoda, slabo educiranom i ostarjelom radnom snagom te „tradicijskom strukturom ruralne svijesti“ (Cifrić, 2013.:267). Jedan od glavnih problema suvremenog sela manjak je socijalnog kapitala jer mlađi i obrazovani i dalje iseljavaju iz ruralnih prostora (Nejašmić, 1991.; Štambuk, 1991.; Štambuk 2002.; Nejašmić i Štambuk, 2003.). Osim ekonomskih razloga, za bijeg iz ruralnih u urbane prostore važni su i socio-psihološki razlozi. Odlazak u grad znači(o) (je) ne samo promjenu gospodarske djelatnosti, vrste zaposlenja nego i promjenu ukupnog načina i stila života pojedinca i obitelji: načina stanovanja, veće mobilnosti, mogućnosti (daljnjeg) obrazovanja, količine i načina provođenja slobodnog vremena, (mogućnosti) konzumiranja kulturnih i za-

1 Površine malih poljoprivrednih gospodarstava čine gotovo polovinu ukupnog obrađenog poljoprivrednog zemljišta u Hrvatskoj. Prema podacima Agencije za plaćanje u poljoprivredi, ribarstvu i ruralnom razvoju, oko 60\% OPG-ova koristi do 3 hektara, dok je samo 2,34\% posjeda veće od 20 hektara, a većih od 50 hektara je svega $0,93 \%$. Upravo je u tijeku izrada novog zakona o komasaciji koja ima za cilj okrupnjivanje posjeda i katastarskih čestica zbog njihova ekonomičnijeg iskorištavanja: stvaranja povoljnijih uvjeta za poljoprivrednu proizvodnju koja bi trebala rezultirati smanjenjem troškova proizvodnje i povećanjem produktivnosti i konkurentnosti. (Jutarnji list, 27. ožujka 2015., Zlatko Šimić „Nova komasacija“, str. 4 i 5 ). 
bavnih sadržaja, niže razine socijalne kontrole itd. (Šuvar, 1972.; Cifrić, 1975.; Podgorelec i Klempić Bogadi, 2013.).

Društvene posljedice kontinuirane i postupne transformacije ruralnih sredina u raznim dijelovima Hrvatske ${ }^{2}$ moguće je pratiti analizom određenih objektivnih i subjektivnih dimenzija svakodnevnog života stanovništva. Pojam „ruralna sredina“ u ovom radu bit će korišten kao termin za „neposrednu fizičku okolinu, društvene odnose i kulturni milje unutar kojeg određena grupa ljudi djeluje pojedinačno i uzajamno" (Barnett i Casper, 2001.:465), a koju po određenim karakteristikama znanstvenici svrstavaju u ruralni prostor.

Bez obzira koje se karakteristike načina života stanovništva nekog područja uspoređuju: demografske, ekonomske, društvene ili kulturološke, podjela među kategorijama urbanost -ruralnost uvijek je arbitrarna. Naime, premda lokacijski pristup pretpostavlja da su ruralna i urbana naselja svrstana u jasne i odvojene dihotomne kategorije, brojni su primjeri isprepletanja određenih urbanih i ruralnih značajki unutar pojedinog naselja, što je utvrđeno istraživanjima načina života stanovništva pojedinih urbanih sredina, primjerice Splita (Klempić Bogadi i Podgorelec, 2014.), ali i nekih pretežno ruralnih, kao što su mali hrvatski otoci (Podgorelec i Klempić Bogadi, 2013.).

Definicije koncepta ruralnosti moguće je grupirati s obzirom na dva dominantna pristupa. Prema prvom, ruralnost određuju društvene i geografske karakteristike prostora, prije svih veličina populacije, gustoća naseljenosti i/ili dominantna vrsta proizvodnje - na prvom mjestu poljoprivreda. Pritom, ruralna su naselja gotovo uvijek manja i slabije gustoće naseljenosti za razliku od urbanih, geografski i društveno izolirana od centara moći dominantno smještenih u urbanim središtima, s prevladavajućim tzv. prirodnim okolišem za razliku od izgrađenog urbanog okoliša (Brown i Schafft, 2011.). Prema M. Štambuk (1991.; 1991.a) trokut selo - poljoprivreda prostor čini osnovicu definiranja ruralnosti, ruralnog svijeta, seoskog društva, ruralnog prostora i svih ostalih sinonima kojima se označavaju područja izvan gradskih aglomeracija, odnosno „[r]aščlamba pojma ruralnosti može se započeti od zemlje, nastaviti se poljoprivredom, zaključiti pejzažom. Ova razina analize obuhvaća, dakle, materijalne uvjete postojanja. I, naravno, način na koji oni stvaraju, "proizvode" snagu kojom selo oblikuje pripadnost sebi ili na koji se način oblikuje pripadnost selu“ (Štambuk, 1993:174).

Teško je precizno odrediti gdje u prostoru prestaje urbano područje, a počinje ruralno. Stoga se za razgraničenje urbanog od ruralnog prostora koriste različiti kriteriji. Prema Milanu Župančiću (2002.:36) ,[...] ruralno obuhvaća seoska naselja, područja i ruralne zone koje nužno uključuju prirodno-pejzažni ambijent, poljoprivredne i šumske površine. No tu spadaju i drugi tipovi naselja - manji gradići, trgovišta i zone

2 Bez obzira na specifičnosti pojedine zajednice s obzirom na geografski položaj (kontinentalna ili otočna naselja), veličinu, stupanj izoliranosti, odnosno perifernosti i neke druge fizičke karakteristike vezane uz ruralnu sredinu. 
polifunkcionalnih namjena i profila koje su, u manjoj ili većoj mjeri, sadržajno vezani uz ruralni svijet. Ovako označeni ruralni se prostor proteže na 85\% do 90\% nacionalnog teritorija“. Naime u Strategiji ruralnog razvoja Republike Hrvatske (2008. - 2013.) kao osnovni kriterij za izdvajanje ruralnih prostora na razini administrativnih jedinica gradova i općina preuzet je kriterij gustoće naseljenosti OECD-a od 150 stanovnika na $\mathrm{km}^{2}$, prema kojem bi čak 91,6\% teritorija Hrvatske imalo ruralne značajke.

Drugi dominantni znanstveni pristup definira ruralnost isključivo kao društveni konstrukt prema kojem su „mjesta ruralna ne zbog strukturnih ili okolišnih karakteristika već zbog ljudi koji tamo žive [...] i doživljaja [...] njihova života [...] određenog [...] društvenim, moralnim i kulturnim vrijednostima [...] idealiziranim krajolikom [...] i/ ili životnim stilom usklađenim s organskim životom zajednice [...] (Brown i Schafft, 2011.: 4-5).

Pristup ruralnosti kao specifičnom višedimenzionalnom konceptu koji određuje kombinacija društvenih, demografskih, ekonomskih i/ili kulturalnih aspekata (Brown i Schafft, 2011.:4) bit će polazište i pri razmatranju odabrane ruralne sredine u ovome radu. Pritom će način života u ruralnoj/im zajednici/ama biti razmatran podjednako u zavisnosti o objektivnim uvjetima (veličina populacija, gustoća naseljenosti), strukturi naselja, ekonomskom temelju (u ovom slučaju, poljoprivredi) i karakteristikama okoliša, kao i o subjektivnim procjenama života zajednice, tj. načinu na koji članovi doživljavaju sebe i svoju ulogu/položaj unutar te zajednice.

Pojam zajednice čvrsto je vezan uz koncept ruralnosti i prema mnogima jasno definira razlike u načinu života između seoskog i gradskog stanovništva. „Zajednica je grupa ljudi organiziranih oko određenih zajedničkih interesa i atributa koji pomažu stvaranju osjećaja zajedničkog identiteta. [...] [Ujedno predstavlja] esencijalne aspekte ljudskog života koji omogućavaju temeljne formalne i neformalne izvore [...] oblikujući važne sastavnice osobnog identiteta" (Brown i Schafft, 2011.:35). Pod pojmom zajednice, premda više kao apstraktan doživljaj negoli nešto konkretno i mjerljivo, obično se podrazumijeva kontinuirana i kvalitetna društvena interakcija među pojedincima koja „doprinosi društvenoj i ekonomskoj produkciji i reprodukciji“ (Selznick, 1992.). Članove zajednice okupljaju zajednička kultura ${ }^{3}$ i društvene vrijednosti, odnosno čvrsta društvena mreža i doživljaj pripadanja (Bell, 1994.; Jones, 1997. prema Woods, 2011.).

\subsection{Osnovna socio-geografska i demografska obilježja istraživanog prostora}

Općina Gornja Rijeka (slika 1.) sastavni je dio Koprivničko-križevačke županije, prostorno smještena na njenoj krajnjoj zapadnoj granici, pa je i geografski, ali i po stupnju gospodarskog i društvenog razvoja periferno područje. Prostire se podno Malog Kalnika, a od najbližeg gradskog centra Križevaca udaljena je 16 km. Zbog takvog prostornog smještaja, s jedne strane, dovoljno je blizu da bi stanovnici općine mo-

\footnotetext{
3 Nerijetko utemeljena na tradiciji.
} 
gli dnevno cirkulirati u najbliži grad zbog školovanja, rada, korištenja zdravstvenih usluga ili zadovoljavanja nekih drugih potreba koje nisu u mogućnosti zadovoljiti u svojoj općini. S druge strane, dovoljno je daleko, pa nije iskorištena kao suburbani prostor Križevaca, odnosno nije došlo do seljenja gradskog stanovništva u okolicu, čime su u načinu života stanovnika naselja općine Gornja Rijeka očuvane temeljne značajke ruralnosti.

Općina Gornja Rijeka ruralno je područje u kojem se stanovništvo nekada bavilo gotovo isključivo poljoprivredom, a s naglom poslijeratnom industrijalizacijom djelomice i kombinacijom rada na zemlji i u industriji. Prema Zakonu o područjima posebne državne skrbi (NN 86/08, 57/11, 51/13, 148/13, 76/14, 18/15) Općina Gornja Rijeka svrstana je u treću skupinu područja posebne državne skrbi Republike Hrvatske, koja zaostaju u razvoju prema trima kriterijima razvijenosti: ekonomskom, strukturnom i demografskom.

Slika 1.

Naselja općine Gornja Rijeka

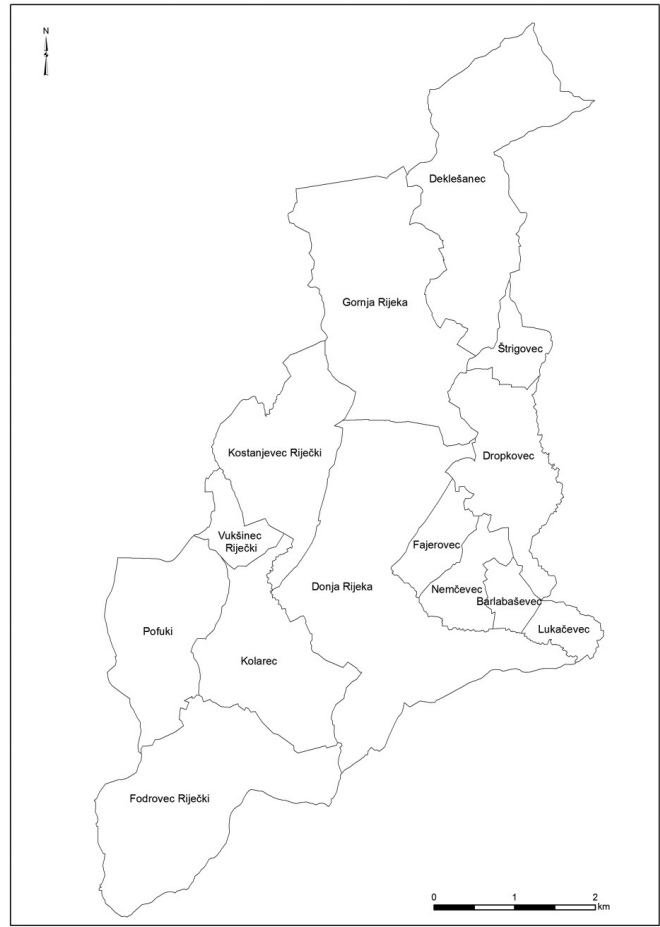

Prema podacima popisa stanovništva 2011. godine, u 14 naselja općine Gornja Rijeka živjelo je 1.779 stanovnika u 503 kućanstva na 32,72 km², što je čini jednom od najmanjih općina u županiji s malim brojem stanovnika. Prosječna gustoća naseljenosti bila je 54,4 stanovnika na $\mathrm{km}^{2}$ i, za usporedbu, manja je od prosječne naseljenosti Koprivničko-križevačke županije sa 66,1 st. $/ \mathrm{km}^{2}$ ili Republike Hrvatske sa 75,7 st. $/ \mathrm{km}^{2}$. Područje općine prostor je $\mathrm{s}$ izrazito malim i patuljastim naseljima. Tako polovica naselja (50\%) ima manje od 100 stanovnika i u njima obitava 17,6\% 
stanovnika općine. Četiri naselja imaju do 50 stanovnika (Barlabaševec, Nemčevec, Lukačevec i Štrigovec), tri naselja od 51 do 100 (Fajerovec, Fodrovec Riječki i Vukšinec Riječki), dva od 101 do 150 stanovnika (Kolarec i Deklešanec) te dva od 151 do 200 stanovnika (Pofuki i Dropkovec). Najveća su naselja Donja Rijeka s 218, Kostanjevec Riječki s 267 i Gornja Rijeka s 340 stanovnika. ${ }^{4}$ Svih 14 naselja okupljenog su ili zbijenog tipa, gdje je većina kuća čelom okrenuta prema cesti, i na njih se straga nadovezuju gospodarske zgrade i obradive površine. Naselja su uglavnom smještena periferno u odnosu na općinsko središte, slabije prometno povezana i u njima dominira staračko stanovništvo. Sva naselja općine karakterizira konstantan pad broja stanovnika, negativna prirodna promjena i visok udio starog stanovništva, što predstavlja veliki problem mogućoj demografskoj revitalizaciji, a time i gospodarskom napretku općine.

\section{Istraživanje}

\subsection{Metoda istraživanja i uzorak}

U nastavku rada bit će analiziran dio rezultata provedenog terenskog istraživanja na uzorku stanovništva svih 14 naselja općine Gornja Rijeka: Gornja Rijeka, Barlabaševec, Deklešanec, Donja Rijeka, Dropkovec, Fajerovec, Fodrovec Riječki, Kolarec, Kostanjevec Riječki, Lukačevec, Nemčevec, Pofuki, Štrigovec i Vukšinec Riječki. Sva navedena naselja, s obzirom na smještenost u prostoru, gustoću naseljenosti, preteŽitu gospodarsku aktivnost stanovništva i neke druge karakteristike, zadovoljavaju kriterije ruralnih naselja i u radu će biti promatrana kao studija slučaja.

Cilj provedenog empirijskog istraživanja bio je produbiti znanstvene spoznaje o kvaliteti života u ruralnim područjima Hrvatske na primjeru općine Gornja Rijeka. IstraŽivanje je provedeno metodom ankete tijekom studenog i prosinca 2012. godine na uzorku od 170 ispitanika starih od 18 do 60 godina, što čini otprilike 10\% ukupnog broja stanovnika općine. Dobna struktura uzorka određena je s ciljem da se sazna procjena objektivnih i subjektivnih domena života stanovništva radno-aktivne dobi. Gornja granica uzorka - 60 godina, odabrana je s obzirom na dob u kojoj je većina stanovnika ruralnih područja (koji uglavnom imaju završeno niže i srednje obrazovanje) ostvarila pravo na mirovinu ${ }^{5}$. S obzirom na dob, 55 ispitanika bilo je u skupini

\footnotetext{
4 Naselja općine Gornja Rijeka prema broju stanovnika iz 2011.: Gornja Rijeka 340, Kostanjevec Riječki 267, Donja Rijeka 218, Pofuki 185, Dropkovec 172, Kolarec 148, Deklešanec 136, Vukšinec Riječki 79, Fajerovec 76, Fodrovec Riječki 61, Štrigovec 37, Lukačevec 23, Barbaleševec 19 i Nemčevec 18. Popis stanovništva, kućanstava i stanova 2011., Statistička izvješća 1468, Stanovništvo prema spolu i starosti, DZS, Zagreb, 2013.

5 Iako, kako su to potvrdila neka istraživanja na hrvatskim otocima, upravo u ruralnim sredinama stanovnici ostvarivanjem formalnih uvjeta (dobi) za odlazak u mirovinu nastavljaju aktivno živjeti do duboke starosti obrađujući zemlju, radeći na okućnici, ribareći i sl. (Podgorelec, 2008.; Klempić Bogadi i Podgorelec, 2011.).
} 
od 18 do 29 godina, 62 starih od 30 do 39 godina, 37 u dobi od 40 do 49 godina i 16 od 50 do 59 godina. Prema spolu, ispitivanjem je bio obuhvaćen podjednak broj žena (50\%) i muškaraca $(50 \%){ }^{6}$

Definicija prema kojoj je kvaliteta života „[...] višeslojni i amorfni koncept [...] koji obuhvaća cjelovitost pojedinčeve percepcije i zadovoljstva tjelesnim zdravljem, psihološkim blagostanjem, samostalnošću, društvenim odnosima, društvenim i materijalnim uvjetima te prirodnim i izgrađenim okolišem [...]“ (Bowling, 2005.: 232) za potrebe ovog rada prilagođena je i mjerena kao subjektivna procjena pojedinčeva života odrednicama osobne kvalitete života: fizičkim, društvenim i duhovnim blagostanjem te općenitim zadovoljstvom životom u ruralnoj sredini (okolišem, zajednicom, lokalnom vlasti).

Zadnjih desetljeća 20. stoljeća hrvatski sociolozi i geografi bavili su se istraživanjima raznih aspekata života stanovništva ruralnih prostora, da bi zadnjih 15-ak godina interes za ovo područje u značajnoj mjeri zamro. Stoga su ciljevi ovoga rada: 1. afirmirati istraživanje ruralnih prostora Hrvatske i 2. analizom dijela provedenog empirijskog istraživanja prezentirati suvremene spoznaje o nekim objektivnim i subjektivnim domenama života u promatranom ruralnom području.

Dakle u radu će biti analiziran samo dio prikupljenih rezultata provedenog istraživanja: potencijalna migracija stanovništva, procjena ekoloških prednosti i nedostataka života u promatranim ruralnim zajednicama, infrastrukturna opremljenost naselja, subjektivna procjena doživljaja pripadanja ruralnoj zajednici te prijedlozi mjera za poboljšanje kvalitete života.

\section{Rezultati i rasprava}

\subsection{Potencijalna migracija}

Kako su i dosadašnja istraživanja potvrdila, migracija je značajno utjecala na način života i oblikovanje socijalne slike ruralnih naselja Hrvatske (Marković, 1974.; Hodžić, 2000.). U manjem broju ruralnih naselja koja su u blizini velikih gradova naglo se povećavao broj stanovnika i izgrađenost naselja, te je došlo do socijalnog prestrukturiranja stanovništva i urbanizacije naselja (Klempić Bogadi, 2010.). Istovremeno u većini drugih ruralnih naselja, koja nisu bila u zoni suburbanizacije, stanovništvo već desetljećima iseljava te naselja demografski slabe, što posljedično utječe na postepeni gubitak sadržaja i ekonomsko zaostajanje jer iseljava uglavnom mlađe, reproduktivno i obrazovanije stanovništvo. Masovni odlazak mladog stanovništva, započet još 1950-ih godina u vrijeme nagle industrijalizacije

${ }^{6} \mathrm{U}$ trenutku provedbe terenskog istraživanja nisu nam bili dostupni podaci o dobno-spolnom sastavu stanovništva općine Gornja Rijeka iz popisa stanovništva 2011. Godine 2011. na području općine živjelo je 898 žena (50,5\%) i 881 muškarac (49,5\%). 
u velikim gradovima, potaknut je mogućnošću zaposlenja na poslovima koji osiguravaju život na višoj ekonomskoj, kulturnoj i tehničkoj razini, osiguravanjem mirovinske i zdravstvene zaštite, mogućnošću dobivanja društvenog stana, ali i načinom života koji se povezuje uz život u gradu (Marković, 1974.; Puljiz, 1977.; Štambuk, 1981.).

Slično kao i u drugim ruralnim općinama, u općini Gornja Rijeka depopulacija se kontinuirano odvija još od popisa stanovništva 1953. godine, prvenstveno zbog emigracije, čiji je dugoročni učinak i negativno prirodno kretanje, te su ta dva čimbenika zajedno dovela do današnjeg demografskog stanja koje obilježava demografska regresija i intenzivno starenje. Seosko stanovništvo je u potrazi za „boljim životom“ emigriralo na rad u obližnje gradove te najviše u Sloveniju (tada još u sastavu bivše države) i inozemstvo (uglavnom u Austriju i Njemačku). Privlačni čimbenici tadašnjeg iseljavanja u Sloveniju za brojne mlade ljude bili su plaćeno školovanje u različitim stručnim školama i mogućnost dobivanja posla. U razdoblju od 1953. do 2011. godine broj stanovnika općine se prepolovio, s 3.513 na 1.779. Najlošija je situacija u naseljima periferno položenim na glavne prometnice u kojima će ubrzo doći i do potpunog nestanka naseljenosti, tj. izumiranja stanovništva.

Jedan od ciljeva istraživanja bio je utvrditi potencijalnu migratibilnost (migraciju) stanovništva općine Gornja Rijeka. Kroz nekoliko pitanja o migraciji nastojalo se ustanoviti pokazuju li ispitanici namjeru preseljenja iz trenutnog naselja stanovanja, postoje li razlike u sklonosti migraciji s obzirom na stupanj zadovoljstva životom na selu, koji su razlozi odlaska i ostanka te koje je potencijalno željeno migracijsko odredište ispitanika.

Prema istraživanju provedenom u prosincu 2006. i siječnju 2007. godine na uzorku od 941 stanovnika u dobi od 25 do 45 godina u 120 seoskih naselja Hrvatske, svaki peti ispitanik namjeravao je odseliti iz svoga sela, a kao najčešći razlog navodili su nezaposlenost i želju za poboljšanjem životne egzistencije obitelji (Žutinić i sur., 2010.). Za razliku od ovog istraživanja, većina ispitanika u općini Gornja Rijeka, njih 63,5\%, nije iskazalo namjeru odseliti iz svog sela, 28,8\% je neodlučno, odnosno odgovorilo je da će možda u skoroj budućnosti napustiti svoje selo, dok svega 7,6\% namjerava odseliti. Razliku u planovima i namjerama za odseljavanjem u dvama navedenim istraživanjima moguće je tumačiti činjenicom da je istraživanje na razini Hrvatske provedeno na uzorku mlađeg stanovništva, koje je obično sklonije migraciji i da je obuhvaćen veliki broj seoskih naselja koja su međusobno znatno razlikuju (prema veličini, položaju, udaljenosti od regionalnog centra, djelatnostima i dr.) nego naselja područja samo jedne općine. Kada u istraživanju ispitanika općine Gornja Rijeka izdvojimo odgovore mlađih ispitanika (18 - 39 godina), nešto je veći udio onih koji namjeravaju odseliti - 9,4\%, kao i onih koji će možda odseliti - 37,6\%, a nešto manji, 53\%, onih koji ne namjeravaju migrirati. Ustanovljena je statistička značajnost između razine obrazovanja i potencijalne migracije ( $\chi^{2}=14,413$, $\mathrm{df}=4, \mathrm{p}=0,006)$. S razinom obrazovanja raste želja za odlaskom sa sela, pa tako $21,7 \%$ ispitanika s višim i visokim obrazovanjem želi odseliti i još 30,4\% o tome razmišlja (odgovor „možda“), dok među onima sa završenom srednjom školom svega 7,2\% sa sigurnošću tvrdi da namjerava odseliti, a 32,4\% o tome razmišlja. 
Bez obzira na odgovor o namjeri migriranja, svi su ispitanici odgovarali na pitanje koji je glavni potisni, a koji privlačni čimbenik pri donošenju potencijalne odluke o preseljenju. Većina ispitanika $(78,2 \%)$ je kao najvažniji razlog za ostanak na selu navela - „zato što im je tu dom i njihova obitelj“. Vrlo sličan razlog navodi još 7,6\% ispitanika - „ovdje žive prijatelji i rodbina“. Najvažniji razlozi ostanka na selu i prednosti seoskog života jesu visoko vrednovanje obitelji i osjećaj pripadanja obitelji, ali i lokalnoj zajednici. I istraživanje provedeno 1970-ih godina u seoskim naseljima Hrvatske, u jeku ruralnog egzodusa, na 1578 ispitanika starih između 15 i 29 godina pokazalo je da seoska omladina pokazuje visoku razinu (emotivne) privrženosti selu, obitelji i prijateljima (Dilić, 1975.). Ruralna društva i zajednice obilježavaju odnosi veće neposrednost i bliskosti, manje kompleksnosti, te se lokalna integracija ostvaruje kroz rodbinske i susjedske odnose, a članovi zajednice pokazuju visoku razinu solidarnosti i međusobne pomoći (Hodžić, 2000.; Župančić, 2002.; Lay, 2002.; Podgorelec i Klempić Bogadi, 2013.). Jedan dio ispitanika $\mathrm{u}$ istraživanju provedenom u naseljima Gornje Rijeke, njih 5,3\%, izražava strah od odlaska iz poznate sredine i života u nekom drugom naselju jer smatraju da bi se „teško negdje drugdje snašli“, 2,4\% ispitanika želi na selu ostati kako bi nastavili upravljati imanjem svojih roditelja, dok 6,5\% ispitanika navodi neke druge, vrlo različite razloge.

Najvažniji čimbenici za potencijalni odlazak sa sela ekonomske su prirode, kao što je pokazalo i istraživanje Žutinić i sur. (2010.). Tako bi 28,2\% ispitanika u općini Gornja Rijeka odselilo zbog zaposlenja, a 30\% zbog boljih uvjeta života. Osnovna motivacija za odlazak sa sela i dalje je ista kao i u vrijeme intenzivnih migracija selo - grad 1960-ih i 1970-ih godina. I tada su osnovne migracijske tendencije bile vezane uz nemogućnost ostvarenja profesionalnih aspiracija, a znatno manje uz psihološku atraktivnost velikih gradova (Dilić, 1975.). Zanimljivo je da čak jedna trećina $(32,4 \%)$ ispitanika ne želi ni razmišljati o tome koji bi mogao biti razlog za odluku o odlasku te izjavljuje da "nikada ne bi napustili svoje selo“. Tek svaki dvadeseti (5,3\%) smatra da ga način života na selu ograničava. Među ostalim mogućim razlozima odlaska (ukupno 2,4\% odgovora) su: „zbog lakšeg obrazovanja svoje djece“, „jedino da ostanu posljednji stanovnici u selu“, „u slučaju neke više sile" itd.

I dok se u doba najintenzivnijeg ruralnog egzodusa 1960-ih i 1970-ih godina privlačnost života u gradu iskazivala u obliku afirmativnih motiva i pozitivnih stereotipa o velegradu (Cifrić, 1975.), od 1990-ih sve su češći pozitivni stavovi i prepoznavanje vrijednosti života na selu - kao mjesto života s prirodom, mirniji tempo Života i sl. U svrhu utvrđivanja migracijskih aspiracija ispitanicima je postavljeno pitanje „Gdje biste najradije živjeli kada biste mogli birati?“. Najveći dio ispitanika izjasnio se da je selo i dalje njihov životni izbor. Tako bi 45,3\% za stanovanje odabralo selo u kojem trenutno živi, a 2,4\% bi rado živjelo u nekom drugom selu. Zagreb kao željeno mjesto stanovanja izabralo bi 7,1\% ispitanika, neki drugi grad u Hrvatskoj 19,4\%, dok bi 25,9\% ispitanika kao novo mjesto stanovanja izabralo neko naselje u inozemstvu. Može se zaključiti da su migracijske aspiracije stanovnika ruralnih područja usmjerene u prvom redu prema gradovima u Hrvatskoj, koji se i dalje percipiraju kao najpoželjnija mjesta za život. Međutim uočljiv je i znatan 
broj onih (četvrtina) koji iskazuju želju za odlaskom u inozemstvo. Razloge treba tražiti u višegodišnjoj nepovoljnoj ekonomskoj situaciji, koja ne daje ispitanicima previše razloga za optimizam i ne otvara perspektivu boljeg života u Hrvatskoj, dok im odlazak u inozemstvo pruža mogućnost ekonomskog napretka i bolje kvalitete života.

Potencijalna migracija ispitanika s obzirom na zadovoljstvo životom u ruralnoj sredini provjerena je statističkim $\chi^{2}$ testom ne bi li se utvrdile razlike u zadovoljstvu životom na selu između ispitanika koji nemaju namjeru napustiti svoje selo i onih koji izražavaju želju za potencijalnom migracijom. Kategorije odgovora na pitanje o namjeri odlaska iz sela uključivale su odgovore: da, ne i možda. Prilikom analize utvrđeno je da ne postoji statistički značajna razlika u zadovoljstvu životom na selu između skupine koja izražava namjere o odlasku i skupine koja preferira ostanak. Većini ispitanika $(53,8 \%)$ koji su se izjasnili za odlazak, kao i onih koji su o toj mogućnosti razmišljali $(59,2 \%)$ život na selu se „sviđa“ ili „jako sviđa“. Rezultati pokazuju da nema razlike u stupnju zadovoljstva životom na selu između ispitanika koji iskazuju migracijske namjere i skupine koja odabire život na selu. Na razmišljanje o seljenju ili donošenju odluke o odlasku utječu na prvom mjestu nepovoljni gospodarski uvjeti, koji određuju ukupnu društvenu klimu u ruralnim prostorima Hrvatske.

\subsection{Opremljenost naselja komunalnom infrastrukturom $i$ društvenim sadržajima}

Infrastrukturna mreža i različiti društveni sadržaji važan su čimbenik u svakodnevnom životu stanovnika i utječu na kvalitetu života u određenom području. Svaki stanovnik, živio u gradu ili na selu, trebao bi imati osiguran barem minimalni društveni standard, tj. da je svakome pod jednakim uvjetima pristupačna komunalna infrastruktura, osnovna škola, medicinska pomoć i sl. (Štambuk, 2002.: 21). U literaturi o kvaliteti života neposredne životne okoline ili susjedstva analiziraju se dvije razine opremljenosti - primarna i sekundarna, čija je ispunjenost uvjet zadovoljstva stanovništva kvalitetom svakodnevnog života (Seferagić, 2005.; Župančić 2005.; Svirčić Gotovac, 2006.). Desetljeća zanemarivanja ruralnog prostora rezultirala su značajnim razvojnim zaostajanjem na svim razinama u odnosu na gradove, odnosno nedostupnošću (ili vrlo niskom kvalitetom) mnogih elementarnih sadržaja. Analiza infrastrukturne opremljenosti hrvatskih sela na razini županija pokazala je da su općenito bolje opremljene one županije koje imaju manji broj seoskih naselja i veći broj stanovnika po naselju (Štambuk i Mišetić, 2002.). Veličina populacije seoskog naselja ključan je čimbenik za opstanak određenih sadržaja. Međutim u razvojnim analizama ruralnih naselja često se zanemaruje značaj tzv. trećih mjesta (Gardner, 2011.: 263-265) koja čine pošta, škola, trgovina, kafić, park ili trg i sl. Ona su bitna za život seoske zajednice ne samo zbog svojih osnovnih funkcija već i kao neformalni javni prostori koji igraju važnu ulogu u strukturi i očuvanosti društvene mreže (mjesta okupljanja i interakcije). Njihovo je postojanje psihološki važno za seosku zajednicu jer su oni simbol života i mogućnosti opstanka malih zajednica (Podgorelec i Klempić Bogadi, 2013.). 
Gotovo svi sadržaji u promatranoj općini smješteni su u naselju Gornja Rijeka, koje je ujedno i sjedište općine. U ovom naselju nalaze se općinski ured, komunalno poduzeće, ambulanta opće i stomatološke medicine Doma zdravlja Križevci, dječja igraonica, knjižnica, osnovna škola „Sidonije Rubido Erdödy“, veterinarska ambulanta veterinarske stanice Križevci, ljekarna, poštanski ured, kafić i kiosk-trgovina mješovite robe te crkva.

Kako bismo utvrdili zadovoljstvo ispitanika stanjem komunalne i društvene infrastrukture općine Gornja Rijeka, ispitanicima je ponuđeno da ocijene 19 sadržaja navedene infrastrukture (ocjenama od 1 do $5^{7}$ ). Najlošiju prosječnu ocjenu $(\mathrm{M}=1,24, \mathrm{SD}=0,49)$ ispitanici su dodijelili opskrbi plinom. Ova ocjena ne začuđuje s obzirom da u općini nije provedene plinofikacija, što mnogi ispitanici smatraju ključnim nedostatkom za značajniji gospodarski razvoj općine. Prema prostornom planu općine, ni u dogledno vrijeme nije planirana izgradnja plinske mreže, što je vjerojatno povezano s malim brojem potencijalnih korisnika i disperziranim razmještajem kućanstava unutar općine. Ispitanici vrlo lošim ocjenjuju veće trgovine, odnosno postojanje supermarketa na području općine $(M=1,95, S D=1,07)$. Naime na području općine nema većih trgovina, a postojeće su loše opskrbljene i namirnice u njima preskupe. Male trgovine, tj. one za dnevnu opskrbu ocjenjuju nešto višom ocjenom, M=3,21, SD=1,10 i one služe ruralnom stanovništvu za zadovoljenje svakodnevnih potreba. Međutim veliki broj naselja na području općine nema stacionarnu trgovinu, pa se opskrba stanovništva prehrambenim proizvodima vrši pokretnom trgovinom. ${ }^{8}$ Ispitanici su nezadovoljni i kanalizacijom i odvodnjom $(\mathrm{M}=2,06, \mathrm{SD}=0,98)$, elementima primarne infrastrukture. Čak $71,7 \%$ ispitanika ocjenjuje ih jako lošima ili lošima. Relativno nisko ocijenjena je i prometna povezanost naselja s ostalim općinama i gradovima (autobus, vlak), M=2,68, SD=1,02 (41,8\% ispitanika ocijenilo lošom ili jako lošom). Slaba prometna povezanost seoskih naselja s lokalnim i regionalnim središtem onemogućuje ruralnom stanovništvu korištenje potrebnih usluga i sadržaja (Župančić, 2002.), ali i dnevnu cirkulaciju na rad u ta naselja, snižava kvalitetu života stanovništva i može biti jedan od značajnijih razloga za iseljavanje. Značajno višu ocjenu dobile su telefonska i internetska mreža $(M=4,02, S D=0,85)$, opskrba električnom energijom $(M=3,91, S D=0,83)$ i pitkom vodom $(M=3,87, S D=0,99)$. Većinu ostalih sadržaja ispitanici ocjenjuju relativno dobrim ocjenama: poštu i veterinarsku stanicu $(\mathrm{M}=3,63, \mathrm{SD}=0,83)$, ambulantu $(\mathrm{M}=3,44, \mathrm{SD}=0,92)$, knjižnicu i dječju igraonicu $(\mathrm{M}=3,41, \mathrm{SD}=0,94)$, crkve i kapelice $(\mathrm{M}=3,90, \mathrm{SD}=0,62)$. Najvišu ocjenu od svih navedenih sadržaja dobila je ljekarna $(\mathrm{M}=4,06, \mathrm{SD}=0,80)$.

${ }^{7}$ Ocjena 1 - jako loše, 2 - loše, 3 - ni loše ni dobro, 4 - dobro i 5 - odlično.

8 U trenutku anketiranja naselje Gornja Rijeka imalo je samo jednu trgovinu (kiosk). Danas naselje ima još dvije trgovine, čime je proširena ponuda namirnica i mogućnost kupovine. 
Tablica 1.

Procjena stanja komunalne i društvene infrastrukture u općini Gornja Rijeka

\begin{tabular}{|c|c|c|c|c|c|c|c|c|}
\hline & & & $\%$ & & & & & \\
\hline & 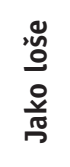 & 㟧 & 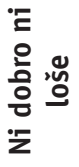 & 은 & 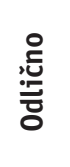 & $\mathbf{N}$ & M & SD \\
\hline $\begin{array}{l}\text { Prometna povezanost naselja s ostalim } \\
\text { općinama i gradovima (autobus, vlak) }\end{array}$ & 14,7 & 27,1 & 34,7 & 22,4 & 1,1 & 170 & 2,68 & 1,02 \\
\hline Ceste (asfalt, makadam) & 4,1 & 15,3 & 30,0 & 47,1 & 3,5 & 170 & 3,31 & 0,92 \\
\hline Kanalizacija i odvodnja & 32,9 & 38,8 & 17,7 & 10,0 & 0,6 & 170 & 2,06 & 0,98 \\
\hline Opskrba električnom energijom & 2,4 & 5,3 & 9,4 & 65,3 & 17,6 & 170 & 3,91 & 0,83 \\
\hline Opskrba plinom & 79,4 & 17,7 & 2,9 & 0 & 0 & 170 & 1,24 & 0,49 \\
\hline Opskrba pitkom vodom & 5,9 & 1,2 & 17,0 & 51,8 & 24,1 & 170 & 3,87 & 0,99 \\
\hline Telefon/Internet & 1,8 & 5,3 & 8,8 & 57,6 & 26,5 & 170 & 4,02 & 0,85 \\
\hline Groblje & 2,3 & 4,1 & 25,9 & 55,3 & 12,4 & 170 & 3,71 & 0,82 \\
\hline Veterinarska stanica & 3,5 & 4,7 & 24,7 & 59,4 & 7,7 & 170 & 3,63 & 0,83 \\
\hline Ambulanta (opće prakse, stomatološka) & 5,3 & 7,1 & 33,5 & 47,1 & 7,0 & 170 & 3,44 & 0,92 \\
\hline Pošta & 3,5 & 3,5 & 12,9 & 62,4 & 17,7 & 170 & 3,87 & 0,87 \\
\hline Ljekarna & 2,3 & 1,8 & 9,4 & 60,6 & 25,9 & 170 & 4,06 & 0,80 \\
\hline Uređenost kuća i okućnica & 2,3 & 10,6 & 45,9 & 34,7 & 6,5 & 170 & 3,32 & 0,84 \\
\hline Stanje crkva i kapelica & 0 & 0,6 & 22,9 & 62,4 & 14,1 & 170 & 3,90 & 0,62 \\
\hline Specijalizirane trgovine (poljoprivredna) & 5,9 & 18,2 & 44,7 & 27,7 & 3,5 & 170 & 3,05 & 0,92 \\
\hline Supermarketi & 45,3 & 27,1 & 17,6 & 7,6 & 2,4 & 170 & 1,95 & 1,07 \\
\hline Trgovine (dnevna opskrba) & 8,2 & 15,3 & 35,3 & 29,4 & 11,8 & 170 & 3,21 & 1,10 \\
\hline Lokalna i područna škola & 1,8 & 4,1 & 24,7 & 58,2 & 11,2 & 170 & 3,73 & 0,78 \\
\hline Knjižnica i dječja igraonica & 4,7 & 9,4 & 34,7 & 42,9 & 8,2 & 170 & 3,41 & 0,94 \\
\hline
\end{tabular}

Analizom varijance željelo se usporediti postoje li veze u ocjeni pojedinih elemenata komunalne i društvene infrastrukture i stupnja sviđanja uvjeta života u ruralnoj sredini. Tako su ispitanici kojima se život u ruralnoj sredini sviđa u usporedbi s onima koji su indiferentni (niti im se sviđa niti ne sviđa) u prosjeku statistički značajno više ocijenili, primjerice, kvalitetu kanalizacijske mreže i odvodnje ( $F=3,510$; $\mathrm{p}=0,032$ ). Ispitanici kojima se ne sviđa život u ruralnoj sredini u usporedbi s ostalim ispitanicima najnezadovoljniji su veterinarskom stanicom $(F=6,069 ; \mathrm{p}=0,003)$, poštom $(\mathrm{F}=6,343 ; \mathrm{p}=0,002)$, ljekarnom $(\mathrm{F}=3,842 ; \mathrm{p}=0,023)$, dok knjižnici i dječjoj igraonici daju prosječno manju ocjenu od indiferentnih ispitanika $(\mathrm{F}=3,939 ; \mathrm{p}=0,021)$.

Nadalje, usporedbom ispitanika na temelju podjele prema procjeni ukupne kvalitete života u ocjenjivanju komunalne i društvene infrastrukture dobivene su sljedeće razlike: ispitanici koji smatraju da imaju najlošiju kvalitetu života daju u prosjeku najmanju ocjenu cestovnoj infrastrukturi $(\mathrm{F}=7,513 ; \mathrm{p}=0,001)$, lokalnoj i područnoj 
Školi $(\mathrm{F}=11,331 ; \mathrm{p}=0,000)$ te knjižnici i dječjoj igraonici $(\mathrm{F}=4,769 ; \mathrm{p}=0,010)$. Isti ispitanici ocjenjuju prometnu povezanost $(\mathrm{F}=4,218$; $\mathrm{p}=0,016)$ i opskrbu pitkom vodom $(\mathrm{F}=5,136 ; \mathrm{p}=0,007)$ lošijom od ispitanika koji svoju kvalitetu života smatraju dobrom ili odličnom. Ispitanici koji kvalitetu života procjenjuju kao ni dobru ni lošu u prosjeku su lošijom ocijenili uređenost kuća i okućnica u odnosu na one koji svoju kvalitetu Života smatraju dobrom ili odličnom ( $F=9,207$; $p=0,000)$.

\subsection{Zadovoljstvo životom u ruralnom prostoru - prednosti i nedostaci}

Stupanj zadovoljstva životom u određenoj sredini povezan je, između ostalog, sa subjektivnim doživljajem mjesta (objektivnih uvjeta) u kojem pojedinac živi. Svi ranije navedeni problemi vezani uz razvoj hrvatskog sela u posljednjih pedesetak godina gradili su sliku načina života povezanog s nerazvijenošću infrastrukture, niskom razinom obrazovanja stanovnika, siromaštvom, nedostatkom mlade radne snage ili, općenito, niskom kvalitetom života. Istovremeno život u gradu smatrao se privilegijom, obećavao veće mogućnosti u svim područjima života, odnosno višu kvalitetu života. Analizom odgovora ispitanika o prednostima i nedostacima života u naseljima općine Gornja Rijeka nastojalo se ustanoviti stupanj zadovoljstva stanovnika životom u promatranom ruralnom prostoru.

Ispitanicima je postavljeno pitanje u kojoj im se mjeri sviđa život na selu. Odgovarali su ponuđenom ljestvicom s pet vrijednosnih sudova: od ,jako mi se sviđa“ do „uopće mi se ne sviđa“. Rezultati su pokazali da se gotovo dvije trećine ispitanika odlučilo za pozitivni dio skale, pri čemu se život na selu ,jako sviđa“ $8,2 \%$ ispitanika, a još $53,5 \%$ se „sviđa“. Nešto manje od trećine ispitanika $(29,4 \%)$ nije se željelo odlučiti ni pozitivno ni negativno („ni sviđa ni ne sviđa“), a svega 8,8\% ispitanika izjasnilo se da im se život u ruralnoj sredini „uopće ne sviđa“ i „ne sviđa“.

Sljedeće pitanje bavilo se procjenom najvećih nedostataka i najvećih prednosti života u pojedinom naselju. Ispitanicima su ponuđeni odgovori među kojima su trebali izabrati tri, po njihovu mišljenju, najveće prednosti i tri najveća nedostatka koji utječu na ukupnu kvalitetu života.

Rangiraju li se odgovori o najvećim nedostacima na razini Općine dobivamo sljedeći redoslijed: nemogućnost zaposlenja (25,1\%), zadiranje u tuđi život $(16,7 \%)$, nedostatak sadržaja za mlade (11,2\%) i (ne)dostupnost trgovine/a (11\%). Ispitanici kao najveći nedostatak života u ruralnom području prepoznaju nemogućnost pronalaženja plaćenog posla u skladu sa svojim obrazovanjem. Naime, u mjeri u kojoj zaposlenje pruža određenu (prije svega materijalnu) sigurnost (stalnost i redovitost prihoda), nemogućnost zaposlenja uzrok je straha, nesigurnosti, ovisnosti o drugima, nezadovoljstva koje nerijetko potiče na razmišljanje ili donošenje odluke o iseljavanju. Visoko drugo mjesto nije pripalo nekom gospodarskom (razvojnom) ograničenju ili infrastrukturnom nedostatku, već društvenom aspektu života zajednice - društvenim vrijednostima i načinu djelovanja društvenih mreža - nedostatku privatnosti. Briga svih o svima problem je koji su isticali ispitanici i u nekim drugim istraživanjima provedenima u ruralnim sredinama, primjerice malim otočnim zajednicama (Pod- 
gorelec i Klempić Bogadi, 2013,.) i za dio njih, i to u nešto većem broju žene, to je jedan od glavnih potisnih čimbenika iseljavanja. Zadiranje u pojedinčevu intimu u malim zajednicama znatno više smeta nove generacije seoskog stanovništva. Naime neke karakteristike i vrijednosti urbanog stila življenja, između ostalih želja za višom razinom privatnosti, sve su prisutnije u načinu života ruralnog stanovništva. I to usprkos i dalje prisutnom snažnom doživljaju pripadanja zajednici (Klempić Bogadi i Podgorelec, 2011.), odnosno procjeni bliskijih kontakata članova ruralnih $(77,8 \%)$ u odnosu na urbane sredine (Žutinić i sur. 2010.:151).

Nedostatak sadržaja za mlade, kao što su razna mjesta za okupljanje, sportska igrališta, disko klubovi i kafići ispitanici različito vrednuju. Svi prepoznaju da je nedostatak sadržaja za mlade veliki problem i svi se slažu da je potrebno izgraditi više mjesta za okupljanje gdje bi se moglo kvalitetno provoditi vrijeme, primjerice sportska igrališta, ali dio starijih zabrinut je zbog mogućeg lošeg utjecaja kafića i disko klubova i njih ne želi u svojim mjestima.

Tablica 2.

Prednosti i nedostaci života u naseljima općine Gornja Rijeka

\begin{tabular}{|c|c|c|}
\hline Prednosti & $\mathbf{N}$ & $\%$ \\
\hline Život u prirodnom okolišu (očuvana priroda, čista i izvorska voda, čist zrak) & 120 & 23,5 \\
\hline Manji troškovi života (samostalna proizvodnja hrane) & 105 & 20,6 \\
\hline Osjećaj sigurnosti veći je na selu u odnosu na grad (manje kriminala) & 94 & 18,4 \\
\hline Smirenost i jednostavnost života (manje stresa, gužve) & 87 & 17,1 \\
\hline Selo čuva tradiciju i običaje (čvršće su obiteljske veze, više se njeguje vjera i vjerski život) & 58 & 11,4 \\
\hline Lakše je podizanje i odgajanje djece & 25 & 4,9 \\
\hline Dobri međuljudski odnosi (bliskost, neotuđenost i složnost između sumještana) & 20 & 3,9 \\
\hline Nešto drugo & 1 & 0,2 \\
\hline Ukupno & 510 & 100,0 \\
\hline Nedostaci & $\mathrm{N}$ & $\%$ \\
\hline Nemogućnost zaposlenja & 128 & 25,1 \\
\hline Nedostatak privatnosti - zadiranje u tuđi život & 85 & 16,7 \\
\hline Nedostatak sadržaja za mlade (mjesto za okupljanje, igralište, disko, kafić) & 57 & 11,2 \\
\hline Pristup trgovini & 56 & 11,0 \\
\hline Pristup obrazovnim ustanovama & 48 & 9,4 \\
\hline Pristup javnom prijevozu & 46 & 9,0 \\
\hline Nedostatak društvenih, kulturnih i sportskih sadržaja (različite manifestacije, sportski turniri) & 44 & 8,6 \\
\hline Pristup zdravstvenim uslugama & 36 & 7,1 \\
\hline Nešto drugo & 10 & 2,0 \\
\hline Ukupno & 510 & 100,0 \\
\hline
\end{tabular}


Među ostalim nedostacima najčešći je odgovor ispitanika udaljenost od obrazovnih ustanova (9,4\%) i neadekvatna organizacija javnog prijevoza (9\%). Za društveni i kulturni život seoskih sredina od posebnog su značaja osnovne škole. Djeca na području općine nastavu pohađaju u osnovnoj školi „Sidonije Rubido Erdödy“ u općinskom središtu, naselju Gornja Rijeka, te u osnovnoj školi „Sv. Petar Orehovec“ u susjednoj istoimenoj općini. Za srednjoškolsko i visokoškolsko obrazovanje mladi trebaju putovati u gradska naselja. Upravo je stoga problem neadekvatnog povezivanja ruralnih naselja s najbližim urbanim veliki ograničavajući čimbenik razvoja i jedan od značajnih potisnih čimbenika iseljavanja ne samo mladih koji odlaze na školovanje nego i cijelih obitelji. U istraživanju razine opremljenosti seoskih naselja i dostupnosti raznih usluga i dobara Župančić (2005.) ustanovljava da 45,8\% seoskih naselja nema ni jednu obrazovnu ustanovu, a 54,2\% pripada kategoriji naselja s lošom opremljenosti obrazovnim ustanovama. Istovremeno $85,7 \%$ istraživanih općinskih središta ima nizak stupanj opremljenosti, 5,7\% uopće nema obrazovnih ustanova, a tek $8,6 \%$ spada u srednji stupanj opremljenosti obrazovnim ustanovama.

Među ostalim nedostacima navedeni su problemi poput malog broja mladih ljudi', nedostatak javnog prostora za veće projekte, problem što u naseljima nema dječjih vrtića $^{10}$, a najbliži se nalazi tek u Križevcima te sve više polupraznih ili napuštenih kuća u selima.

Među navedenim prednostima života u ruralnom području u prvom su rangu ekološke prednosti (vrijednosti) prostora - očuvana priroda, čista i izvorska voda, čist zrak $(23,5 \%)$. Stanovnici ruralnih područja i dalje nastoje živjeti u harmoniji s prirodom i još uvijek visoko vrednuju zdrav okoliš. Na drugom mjestu (20,6\%) nalaze se niži troškovi života u ruralnoj sredini u odnosu na urbanu kao i mogućnost ostvarenja prihoda od rada na zemlji. Mogućnost samostalne proizvodnje hrane nekima predstavlja glavni (i jedini) izvor prihoda, a nekima je odličan izvor dopunske zarade za kućanstvo. Mogućnost proizvodnje hrane za osobne potrebe kao izvor dopunske zarade prepoznata je kao značajna prednost života u ruralnim sredinama (Podgorelec, 2008.; Podgorelec i Klempić Bogadi, 2013.). ${ }^{11}$ Na trećem mjestu (18,4\%) veći je osjećaj (fizičke) sigurnosti stanovnika na selu u odnosu na stanovnike u gradu (Klempić Bogadi i Podgorelec, 2009.), posebice u malim ruralnim zajednicama kakvima pripadaju ispitanici obuhvaćeni istraživanjem u naseljima općine Gornja Rijeka. Naime u takvim je malim zajednicama visok stupanj socijalne kontrole - „zna se kako tko diše“, svatko svakoga poznaje, stranci rijetko dolaze pa je kontrola jača i stopa kriminala niža. U ekološke vrijednosti seoskog načina života ubrojeni su i smireniji (polaganiji) tempo života i određena jednostavnost života $(17,1 \%)$.

9 Isti problem ističu ispitanici u istraživanju kvalitete života na šibenskim otocima (Podgorelec i Klempić Bogadi, 2013.; Podgorelec, 2008.).

10 Problem nemogućnosti socijalizacije djece u okviru dječjih ustanova na manjim hrvatskim otocima jedan je od razloga iseljavanja mladih obitelji (Podgorelec i Klempić Bogadi, 2013.). 11

Pojam seljak-radnik poznat je u ruralno sociološkoj literaturi kao fenomen značajan zbog očuvanja i održanja poljoprivredne djelatnosti u većini ruralnih područja u nas, naročito onima manje poljoprivrednima, poput Dalmacije. 


\subsection{Društveni život}

Društveni život stanovništva ruralnih sredina znatno se razlikuje od života urbanog stanovništva. Dok grad nudi brojne kulturne, zabavne i sportske sadržaje u raznim institucijama, selo svojim mještanima nudi prostor društvenog doma kao mjesto okupljanja i provođenja slobodnog vremena. Razne udruge i društva organizatori su raznih zbivanja, okupljaju stanovništvo oko zajedničkih interesa i vrijednosti te pomažu očuvanju osjećaja zajedništva, pripadanja i identiteta zajednice. Organizacijom života zajednice razvijaju se i čuvaju postojeće društvene mreže i socijalni kapital zajednice. Na području općine Gornja Rijeka djeluje nekoliko sportskih, lovačkih i dobrovoljnih vatrogasnih društava te udruga Potkalničkih plemenitaša koji rade na promicanju kulturno-povijesne baštine i prirodnih ljepota kalničkog prigorja.

Istražujući stvarnu ulogu navedenih društava u očuvanju, ali i oživljavanju nekih tradicionalnih vrijednosti u ruralne sredine utvrđeno je kako 65,9\% ispitanika procjenjuje da lokalna društva imaju ključnu ulogu u revitalizaciji ruralnih sredina. Lokalna društva u suradnji s lokalnom vlašću nosioci su razvoja sela, zaslužni za organizaciju kulturnih, edukativnih i sportskih događaja, kao što pokazuje i sljedeći iskaz dobiven u razgovoru s ispitanicima:

„Svako društvo, bilo ono lovačko, sportsko ili vatrogasno okuplja mještane svih generacija koji su voljni sudjelovati i doprinositi lokalnoj zajednici. Društva često organiziraju sportska natjecanja u naseljima općine, ali i izvan nje, čime sudionici imaju priliku vidjeti druge krajeve, upoznati nove ljude i običaje domaćina. Osim toga, imamo priliku promovirati sredinu iz koje dolazimo i predstaviti njezine potencijale." (M, 38).

Dio ispitanika koji postojećim društvima pripisuje ograničenu mogućnost djelovanja na socijalni kapital zajednice objašnjavaju to, između ostalog, i nedostatnim financijskim sredstvima kojima raspolažu, ali i ograničavajućom ponudom koja se uglavnom svodi na čuvanje tradicijskih vrijednosti.

Ispitanici ističu da se način provođenja slobodnog vremena u selu bitno izmijenio. Mlađe generacije žele upotpuniti svoje slobodno vrijeme raznim aktivnostima kao što su nogomet, stolni tenis, sviranje glazbenih instrumenata, šah i sl. U procesu realizacije svojih ideja pristupaju obnovi i uređenju društvenih domova, uređenju igrališta, izgradnji parkova, organizaciji međuseoskih sportskih natjecanja, a sve u svrhu što kvalitetnijeg života i provođenja vremena u svom kraju.

Zabilježena je i sljedeća izjava jednog ispitanika: „Kroz razne sportske događaje mladi se stalno druže, stječu nova iskustva i prijatelje. Često se organiziraju radne akcije u svrhu obnove ili izgradnje novih sadržaja koji pridonose društvu i okolini. Svako sportsko društvo ima svoje članove koji se trude da obnove stara igrališta i urede parkove u selu. Naposljetku, kroz taj rad se svi zajedno družimo i surađujemo. Sportska društva svakako pozitivno utječu na promjene u okolini mojeg kraja." (M, 18).

U nedostatku drugih sadržaja i javnih prostora, društveni domovi i dalje su važni za društveni život svakoga sela, te je njihovo održavanje i obnova od velikog značaja 
za ruralno stanovništvo. U njima se održavaju različiti kulturni, zabavni i edukativni programi namijenjeni svim stanovnicima sela. I ovo je istraživanje potvrdilo rezultate nekih ranijih da je postojanje i djelovanje seoskih društava vrlo važno jer „[...] organiziraju seoske radne akcije za unapređenje kvalitete življenja, sakupljaju samodoprinose, održavaju međusobnu pomoć, razne zabave i što je važno za ovu temu, identificiraju se sa cijelom zajednicom i održavaju njezine interne odnose. Često preuzimaju ulogu formalnih teritorijalno-političkih organizacija (npr. mjesnih odbora)." (Seferagić, 2002.:23).

\subsection{Prijedlozi mjera za poboljšanja kvalitete života u općini Gornja Rijeka}

Postavljanjem dvaju otvorenih pitanja u upitniku od ispitanika se tražilo da iznesu vlastito mišljenje o tome što bi oni kao pojedinci mogli učiniti za poboljšanje kvalitete života na području općine te da predlože neke mjere kojima bi općina ili županija mogle pridonijeti poboljšanju života. Odgovori su nakon obrade grupirani u nekoliko kategorija s obzirom na učestalost pojavljivanja.

Mnogi ispitanici ostali su zatečeni pitanjima o mogućnosti vlastitog utjecaja na promjene životnih uvjeta i iznošenje prijedloga mjera koje bi ublažile negativne društvene i gospodarske procese na području općine. Iz odgovora je jasno da mnogi nisu o tome razmišljali, ali i da nisu naviknuti na takav način odlučivanja, tj. da mogu sami kreirati politiku razvoja i utjecati (makar idejom) na unapređenje kvalitete života svog područja. M. Štambuk (2002.:20-21) ističe da je za razvoj ruralnih područja bitno „[...] poticanje društvene i gospodarske heterogenosti, koja će se temeljiti prije svega na istraživanju, valorizaciji i upotrebi endogenih izvora, uključujući znanja i iskustva lokalnog stanovništva i, naravno njihovo primjereno obrazovanje za razvoj“. Stoga obeshrabruje činjenica da više od trećine ispitanika $(37,6 \%)$ smatra da oni kao pojedinci ništa ne mogu učiniti za poboljšanje života na području općine. Pritom ispitanici navode da premda mogućnost poboljšanja uvijek postoji, oni kao pojedinci nemaju tu moć, odnosno ovlasti pokrenuti potrebne promjene, već je to u nadležnosti lokalne vlasti. Ako ovoj skupini dodamo dio ispitanika $(13,5 \%)$ koji ne zna što bi kao pojedinci mogli promijeniti u svojoj sredini, tada se više od pola ispitanika smatra nekompetentnima raspravljati o načinima poboljšanja raznih područja života u svome naselju. Ispitanici pritom pokazuju visoku razinu pasivnosti, pa čak i nezainteresiranosti za preuzimanje aktivnije uloge u lokalnom razvoju. Većina ih očekuje inicijativu ljudi izvan lokalne zajednice, koji bi svojim idejama i ulaganjima potaknuli gospodarski razvoj, a time unaprijedili ukupnu kvalitetu života na promatranom području.

Da pojedinci mogu vrlo malo učiniti za poboljšanje života u svojoj sredini smatra 5,9\% ispitanika. Potrebno je poći od sebe, „voditi brigu o svom dvorištu“, urediti vlastiti dom, gospodarstvo i okoliš, misli 3,5\% ispitanika. ${ }^{12}$ Sudjelovanje u nekoj zajedničkoj akciji uređenja ili humanitarnoj akciji jedan je mogući način poboljšanja

12 Od 2014. godine pokrenuti su natječaji za poticanje korištenja obnovljivih izvora energije u obiteljskim kućama, poticanje mjera energetske učinkovitosti (fasade, stolarija...) na obiteljskim kućama u općini Gornja Rijeka. 
Života u njihovoj sredini (4,7\% ispitanika). Dio ispitanika (4,7\%) smatra da bi zapošljavanjem mogli doprinijeti podizanju osobne kvalitete života (zadovoljstva i sreće) i time utjecati na opću kvalitetu. Nešto više je onih (6,5\%) koji smatraju da bi mladi intelektualci novim programima mogli (i trebali) pokrenuti razvoj općine i poboljšati trenutne uvjete života, a 5,3\% ispitanika misli da bi pokretanjem vlastite proizvodnje poboljšali ukupnu kvalitetu života. Objašnjavaju da ne samo da bi pokretanjem vlastite proizvodnje bili uspješan primjer ostalim sumještanima već bi omogućili zapošljavanje većeg broja ljudi, ulagali u svoj kraj i radili za dobrobit zajednice. Mali dio ispitanika $(4,1 \%)$ zaključuje da se aktivnim uključivanjem u društveni i politički život općine može pridonijeti poboljšanju kvalitete života.

Tablica 3.

Što biste vi kao pojedinac mogli učiniti za poboljšanje života u ruralnom prostoru?

\begin{tabular}{|l|c|c|}
\hline & N & \% \\
\hline Ništa kao pojedinac & 64 & 37,6 \\
\hline Ne znam & 23 & 13,5 \\
\hline Prepustiti općinu mladim intelektualnim ljudima da pokrenu razvoj & 11 & 6,5 \\
\hline Jako malo & 10 & 5,9 \\
\hline Pokrenuti vlastitu proizvodnju & 9 & 5,3 \\
\hline Sudjelovati u nekoj akciji uređenja ili humanitarnoj akciji & 8 & 4,7 \\
\hline Zaposliti se & 8 & 4,7 \\
\hline Aktivno se uključiti u društveni i politički život općine & 7 & 4,1 \\
\hline Urediti najprije „svoje dvorište“ & 6 & 3,5 \\
\hline Ostalo & 24 & 14,1 \\
\hline Ukupno & 170 & 100,0 \\
\hline
\end{tabular}

Tablica 4.

Prijedlozi mjera kojima bi općinska ili županijska uprava mogla poboljšati život na području općine Gornja Rijeka

\begin{tabular}{|l|c|c|}
\hline & N & \% \\
\hline Ne znam & 47 & 22,9 \\
\hline Povećati zaposlenost & 39 & 19,0 \\
\hline Ulaganje u društvenu i komunalnu infrastrukturu & 38 & 18,5 \\
\hline Podrška mladima & 10 & 4,9 \\
\hline Poticanje razvoja lokalnog poduzetništva & 9 & 4,4 \\
\hline Ulaganje u razvoj turizma (seoski, izletnički, sportsko - rekreativni) & 6 & 2,9 \\
\hline Potpore poljoprivredi & 6 & 2,9 \\
\hline Uspostavljanje bolje suradnje s mještanima & 6 & 2,9 \\
\hline Poticanje samozapošljavanja & 4 & 2,0 \\
\hline Pružanje pomoći potrebitima (siromašnima, starijima i nemoćnima) & 3 & 1,5 \\
\hline Ostalo & 37 & 18,0 \\
\hline Ukupno & 205 & 100,0 \\
\hline
\end{tabular}


Kod pitanja: „Navedite neke mjere kojima bi općina ili županijska uprava mogla poboljšati život na području općine" ispitanicima je omogućeno da navedu onoliko mjera koliko smatraju da je potrebno za kvalitetnije življenje. Najčešći odgovor bio je „ne znam“ (22,9\%). Ključna mjera za poboljšanje života u općini, prema mišljenju $19 \%$ ispitanika, otvaranje je novih radnih mjesta i povećanje zaposlenosti. Ističe se i važnost ulaganja u društvenu i komunalnu infrastrukturu $(18,5 \%)$ navođenjem sljedećih mjera: pitka voda za sve, uređenje mjesta i dječjih igrališta, izgradnja kanalizacije, uređenje lokalnih poljskih putova, dogradnja školske dvorane i uređenje škole, više kulturnih događaja, opremljenost naselja trgovinama, obnova ambulanta i sl. Ova je primjedba značajna upravo stoga što ukazuje na neadekvatnu i nezadovoljavajuću opremljenost seoskih naselja čak i u elementima primarne infrastrukture, čime nisu zadovoljeni ni osnovni uvjeti za ukupnu kvalitetu života. Zadržavanje takvog stanja ne pruža mogućnost kvalitetnog planiranja razvoja promatranog područja.

Dio ispitanika (4,9\%) smatra važnom mjerom napretka pružanje podrške mladima. Potrebno je podržati njihove ideje, ali i u svrhu poboljšanja obrazovne strukture sela poticati ih na visoko obrazovanje, dodjeljivati stipendije najboljima, omogućiti im da kreativno provode svoje vrijeme, organizirati tečajeve i radionice na kojima bi usavršavali dosad stečena znanja i razmjenjivali ideje. ${ }^{13}$ Kao važan čimbenik unaprjeđenja života ruralnog stanovništva prepoznata je i potreba poticanja razvoja lokalnog poduzetništva $(4,4 \%)$.

Preostali prijedlozi pojavljuju se znatno rjeđe, pa će ovdje biti samo nabrojeni: ulaganja u razvoj turizma (posebice seoskog, izletničkog i sportsko-rekreativnog turizma), dijeljenje potpora poljoprivrednoj proizvodnji, poboljšanje suradnje $s$ mještanima, pružanje pomoći potrebitima (napose siromašnima, starijima i nemoćnima) te poticanje samozapošljavanja. Gotovo petina ispitanika (18\%) navela je različite mjere za poboljšanje kvalitete života na području svih naselja općine Gornja Rijeka koje bi zajednički trebale provesti Općina i Županija. Odgovori obuhvaćaju prijedloge: osnivanje turističke zajednice, ravnopravnost svih mještana, poduzimanje mjera protiv iseljavanja stanovništva, izmjena vlasti, zapošljavanje logopeda u osnovnoj školi, poticanje razvoja ruralnih područja jer su budućnost zdravog života, pokretanje sadržaja za mlado i starije stanovništvo, uvođenje dodatne linije školskog autobusa za djecu na području naselja Gornja Rijeka i Deklešanec itd. Iz nekih odgovora stanovnika može se iščitati svojevrsno nepovjerenje prema nositeljima lokalne i županijske vlasti, pa se čini neophodnim u buduće razvojne planove općine u većoj mjeri uključivati mještane kako bi se gradilo povjerenje između stanovnika i nositelja vlasti, što je bitan preduvjet uspješne implementacije razvojnih planova.

13 U prosincu 2014. godine donesen je pravilnik o stipendiranju studenata preddiplomskog, diplomskog i poslijediplomskog studija s područja općine Gornja Rijeka. 


\section{Zaključak}

Iako je jedan od ključnih ciljeva brojnih strategija razvoja Republike Hrvatske uravnoteženi regionalni razvoj i poboljšanje kvalitete života u ruralnim područjima, u posljednjih 20-ak godina u tom području nije došlo do značajnijih pozitivnih kretanja. Općina Gornja Rijeka dijeli sličnosti s većinom ruralnih područja u Hrvatskoj, koje karakterizira ekonomska nerazvijenost i demografska regresija. Depopulacija i starenje kao dominantni demografski procesi oblikuju malu zajednicu koju obilježava slabija obrazovna struktura stanovnika, što uz gotovo nepostojeću lokalnu inicijativu čini ograničavajuće čimbenike za pokretanje gospodarskih aktivnosti.

Kako bi bilo koji razvojni program bio uspješno osmišljen i implementiran, nužno je u proces odlučivanja uključiti i članove lokalne zajednice, a njihovi se interesi ne smiju ignorirati zbog eventualnog ekonomskog profita. Problem je što većina ruralnih lokalnih zajednica, pa su tako i promatrane, teško artikuliraju svoje potrebe i ideje, nerijetko iskazuju znatnu inertnost, a nedostaje im i povjerenja prema idejama koje dolaze izvana. Jedan od ispitanika opisao je stanje u općini riječima: „Općina je vrlo siromašna i bezidejna, a županijskoj smo upravi nezanimljivi. Tužno!“. Istraživanje je potvrdilo da velik dio ispitanika ne zna kako bi oni sami ili lokalna i županijska vlast mogli pozitivno djelovati na unaprjeđenje kvalitete života njihove ruralne zajednice. Brojni primjeri provedenih razvojnih projekata u ruralnim zajednicama u svijetu pokazali su da je za konačan uspješan rezultat u projekt neophodno uključiti lokalne aktere, voditi računa o prirodnim resursima i dugoročnoj održivosti razvoja. Budući razvoj općine Gornja Rijeka ovisi o suradnji na više razina upravljanja. Osim o provedbi kvalitetnih programa razvoja ruralnih prostora na razini Hrvatske, buduća ulaganja u prostor kroz komunalnu i društvenu strukturu te u razvoj gospodarstva, a što bi rezultiralo povećanjem životnog standarda i ukupne kvalitete života stanovništva, ovise i o unapređenju uzajamnog povjerenja mještana i lokalne vlasti.

Usprkos brojnim ograničavajućim čimbenicima života u naseljima Općine Gornja Rijeka, rezultati istraživanja potvrdili su relativno visok stupanj zadovoljstva stanovništva životom u ruralnoj sredini, uz očekivanja unapređenja određenih, njima iznimno važnih, sadržaja društvene i komunalne infrastrukture. Svjesni brojnih prednosti života u ruralnim sredinama, svega što se u literaturi o ruralnim prostorima naziva ruralnom idilom (očuvana priroda, čist zrak, smirenost i jednostavnost života, niži troškovi života, doživljaj bliskosti i pripadanja), stanovnike hrvatskih ruralnih prostora višedesetljetno gospodarsko zanemarivanje nerijetko prisiljava na razmišljanje o migraciji.

\section{Literatura}

1. Barnett, E. i Casper, M. (2001). Research - A Definition of „Social Environment“. American Journal of Public Health, 91 (3): 465.

2. Bowling, A. (2005). Ageing Well: Quality of Life in Old Age. Maidenhead: Open University Press. 
3. Brown, D. L. and Schafft, K. A. (2011). Rural People and Communities in the $21^{\text {st }}$ Century: Resilience and Transformation. Cambridge: Polity.

4. Cifrić, I. (1975). Privlačnost Zagreba kao velikog grada. Revija za sociologiju, 5 (4): 82-92.

5. Cifrić, I. (2013). Iskustvo seljačkog društva. Poruka modernom društvu, Sociologija i prostor, 51 (2): 265-279.

6. Dilić, E. (1975). Migracijske tendencije seoske omladine. Sociologija sela, 49-50, 54-67.

7. Hodžić, A. (2000). Socijalna struktura i mobilnost seoskog stanovništva. Sociologija sela, 38 (1/2): 79-107.

8. Gardner, P. J. (2011). Natural Neighborhood Networks - Important Social Networks in the Lives of Older Adults Aging in Place. Journal of Aging Studies, 25: 263-271.

9. Klempić Bogadi, S. (2010). Populacijski razvoj gradskih regija Hrvatske 1948.2001., u: Lajić, I. (ur.). Migracije i regionalni razvoj Hrvatske. Zagreb: Institut za migracije i narodnosti: 23-62.

10. Klempić Bogadi, S. i Podgorelec, S. (2009). Sociodemografske značajke i procesi u hrvatskim obalnim gradovima. Geoadria, 14 (2): 221-247.

11. Klempić Bogadi, S. i Podgorelec, S. (2011). Sociogeografske promjene u malim otočnim zajednicama - primjer otoka Zlarina. Geoadria, 16 (2): 189-209.

12. Klempić Bogadi, S. i Podgorelec, S. (2014). Split - na dodiru ruralnog i urbanog, u: L. Mirošević i V. Graovac Matassi (ur.). Dalmacija u prostoru i vremenu - Što Dalmacija jest, a što nije?. Zadar: Sveučilište u Zadru.

13. Lay, V. (2002). Prilozi osmišljavanju usmjeravanja razvitka ruralnih prostora Hrvatske na osnovama ekološke i gospodarske održivosti, u: Rogić, I., Štambuk, M. i Mišetić, A. (ur.). Prostor iza. Kako modernizacija mijenja brvatsko selo. Zagreb: Institut društvenih znanosti „Ivo Pilar“: 289-304.

14. Marković, P. (1974). Migracije i promena agrarne strukture. Zagreb: Centar za sociologiju sela, grada i prostora Instituta za društvena istraživanja Sveučilišta u Zagrebu.

15. Nejašmić, I. (1991). Moguća revitalizacija sociodemografskih depresivnih (seoskih) prostora Hrvatske. Sociologija sela, 111-114: 11-24.

16. Nejašmić, I. i Štambuk, M. (2003). Demografsko stanje i procesi u neurbanim naseljima RH. Društvena istraživanja, 12 (3-4): 469-493.

17. Podgorelec, S. (2008). Ostarjeti na otoku - Kvaliteta života starijega stanovništva hrvatskih otoka. Zagreb: Institut za migracije i narodnosti.

18. Podgorelec, S. i Klempić Bogadi, S. (2013). Gradovi potopili škoje-Promjene u malim otočnim zajednicama. Zagreb: Institut za migracije i narodnosti.

19. Puljiz, V. (1970). Mješovita gospodarstva u socijalno-ekonomskoj strukturi našeg sela. Sociologija sela, 29-30: 92-104.

20. Puljiz, V. (1977). Eksodus poljoprivrednika. Zagreb: Centar za sociologiju sela, grada i prostora Instituta za društvena istraživanja Sveučilišta u Zagrebu.

21. Selznick, P. (1992). The Moral Commonwealth: Social Theory and the Promise of Community. Berkeley: University of California Press.

22. Seferagić, D. (2002). Selo između tradicionalne i virtualne zajednice, u: D. Seferagić (ur.). Selo: izbor ili usud. Zagreb: IDIZ.

23. Seferagić, D. (2005). Piramidalna mreža gradova. Sociologija sela, 43 (3), 579615. 
24. Strategija ruralnog razvoja Republike Hrvatske 2008. - 2013., Ministarstvo poljoprivrede, ribarstva i ruralnog razvoja, Zagreb. pregledano, 3. veljače 2015. (http://seerural.org/1documents/Strategic Documents2/Croatia/Strategija ruralnog_razvoja_Republike_Hrvatske za_razdoblje_2008_2013.pdf).

25. Svirčić Gotovac, A. (2006). Kvaliteta stanovanja u mreži naselja Hrvatske. Sociologija sela, 44 (1): 105-126.

26. Štambuk, M. (1981). O pokretljivosti seoskog stanovništva. Revija za sociologiju, $11(3-4): 125-130$.

27. Štambuk, M. (1990). Neke značajke ruralnog prostora, u: D. Seferagić (ur.). Promjene u svakodneunom životu sela i grada. Zagreb: Institut za društvena istraživanja Sveučilišta u Zagrebu.

28. Štambuk, M. (1991). Društvene mijene ruralnog prostora Hrvatske. Sociologija sela, 111-114: 1-10.

29. Štambuk, M. (1991a). Socijalna dinamika u seoskoj zajednici, u: D. Seferagić (ur.). Društvene promjene u prostoru. Zagreb: IDIS.

30. Štambuk, M. (1993). Od "stare” k "novoj" ruralnosti. Sociologija sela, 121-122: 173-182.

31. Štambuk, M. (2002). Selo i modernizacija: kratka povijest nesporazuma, u: Rogić, I., Štambuk, M. i Mišetić, A. (ur.). Prostor iza. Kako modernizacija mijenja hrvatsko selo. Zagreb: Institut društvenih znanosti „Ivo Pilar“.

32. Štambuk, M., Mišetić, A. (2002). Neki elementi socijalne i tehničke infrastrukture hrvatskog sela, u: Rogić, I., Štambuk, M. i Mišetić, A. (ur.). Prostor iza. Kako modernizacija mijenja hrvatsko selo. Zagreb: Institut društvenih znanosti „Ivo Pilar".

33. Šuvar, S. (1972). Neki aspekti konfliktnih odnosa selo-grad u našem društvu. Sociologija sela, 35-36: 3-15.

34. Woods, M. (2011). Rural Geography: Processes, Responses and Experiences in Rural Restructuring. London: Sage.

35. Župančić, M. (2002). Vitalni poljoprivrednici i drugi akteri u razvoju ruralnih područja, u: D. Seferagić (ur.). Selo: izbor ili usud. Zagreb: IDIZ.

36. Župančić, M. (2005). Infrastrukturna opremljenost hrvatskih seoskih naselja. Sociologija sela, 43 (3): 617-657.

37. Žutinić, Đ., Kovačić, D., Grgić, I., Markovina, J. (2010). Percepcija kvalitete Življenja i namjere o odlasku iz ruralnih sredina. Društvena istraživanja, 19 (12): $137-159$.

\section{Izvori}

Jutarnji list, 27. ožujka 2015., Zlatko Šimić „Nova komasacija“, str. 4 i 5.

Popis stanovništva, kućanstava i stanova 2011., Statistička izvješća 1468, Stanovništvo prema spolu i starosti, DZS, Zagreb, 2013.

Zakonu o područjima posebne državne skrbi, Narodne novine 86/08, 57/11, 51/13, $148 / 13,76 / 14,18 / 15$ 
Izvorni znanstveni rad

\title{
Sanja Klempić Bogadi
}

Institute for Migration and Ethnic Studies, Zagreb, Croatia

e-mail: sanja.klempic@imin.hr

Sonja Podgorelec

Institute for Migration and Ethnic Studies, Zagreb, Croatia

e-mail:sonja.podgorelec@imin.hr

Monika šabijan

Dropkovec, Croatia

e-mail:monika.sabijan@gmail.com

\section{Croatian Village at the Beginning of the $21^{\text {st }}$ Century - Case Study of the Municipality of Gornja Rijeka}

\begin{abstract}
The paper presents a part of the results of the empirical research aimed at deepening scientific knowledge about the quality of life in rural areas in Croatia on the example of the municipality of Gornja Rijeka. Potential population migration, evaluation of environmental advantages and disadvantages of living in the observed rural communities as well as the infrastructural facilities of settlements, the subjective assessment of the experience of belonging to a rural community, and proposed measures to improve the quality of life have been analyzed. The research was conducted by using the questionnaire method during November and December 2012 on a sample of 170 respondents aged 18 to 60, accounting for about 10 $\%$ of the total population of the municipality.
\end{abstract}

The municipality of Gornja Rijeka shares similarities with most rural areas in Croatia that are characterized by economic underdevelopment and demographic regression. Depopulation and ageing, as the dominant demographic processes, shape the small community marked by a lower level of educational population structure which, along with almost no local initiative, represent limiting factors for boosting economic activities.

Despite a number of limiting factors of life in this area, the respondents express a high degree of satisfaction with life in rural areas, but they also note that some contents of social and communal infrastructure need to be significantly improved. Although being aware of the many advantages of living in rural areas, such as well-preserved nature, clean air, tranquility and simplicity of life, and lower cost of living, economic reasons force them to think about migration.

Key words: village, municipality of Gornja Rijeka, rurality, migration, infrastructure, quality of life. 